\title{
Evaluation of a standard artificial flower design to feed individual bees known amounts of pesticides ${ }^{1}$
}

\author{
Edith LADURNER $^{\mathrm{a} *}$, Jordi BOSCH${ }^{\mathrm{b}, \mathrm{c}}$, William P. KEMP ${ }^{\mathrm{d}}$, Stefano MAINI ${ }^{\mathrm{a}}$ \\ a Dipartimento di Scienze e Tecnologie Agroambientali - Area Entomologia, Università di Bologna, \\ Viale Fanin 42, 40127 Bologna, Italy \\ b Biology Department, Utah State University, Logan, UT 84322-5310, USA \\ c Unitat d'Ecologia/CREAF, Universitat Autònoma de Barcelona, 08193 Bellaterra, Spain \\ d USDA - ARS, Bee Biology \& Systematics Laboratory, Logan, UT 84322-5310, USA
}

Received 24 May 2004 - revised 9 November 2004 - accepted 12 November 2004

Published online 7 July 2005

\begin{abstract}
We investigated the possibility of feeding individual bees known amounts of pesticides on a standard artificial flower with or without scent. We tested experienced and naive (without foraging experience) Osmia lignaria and Megachile rotundata females, and experienced Apis mellifera foragers, and trained (exposed to the artificial flower for $24 \mathrm{~h}$ ) and untrained individuals of the three species. We also fed untrained individuals of all three species with feeding units made with natural flowers (Ladurner et al., Apidologie 34 (2003) 597-602). Feeding success on artificial flowers was lower (0-50\%) for O. lignaria and $M$. rotundata, than A. mellifera (70-97\%). Training improved feeding success in $O$. lignaria and A. mellifera, but not $M$. rotundata. Experience improved feeding success in $O$. lignaria, but not $M$. rotundata. Scent had no effect on feeding success for any of the three species. Feeding success with the natural flower method was high for the three species (87-90\%).
\end{abstract}

oral toxicity test / artificial flower / Osmia lignaria / Apis mellifera / Megachile rotundata

\section{INTRODUCTION}

In 2002, we initiated investigations on the effect of pesticide sprays on the solitary bee Osmia lignaria Say (Megachilidae), a species increasingly used as an orchard pollinator in North America (Bosch and Kemp, 2002). Group feeding methods, used with Apis mellifera L. (Apidae) in laboratory acute toxicity studies (OEPP/EPPO, 1992, 2001), cannot be applied to most other bee species, which, like $O$. lignaria, do not perform trophallaxis. In fact, acute toxicity studies on non-Apis bees often omit oral tests because it is difficult to feed individual bees known amounts of test solutions (Taséi, 2002). We therefore devised a simple method to feed bees individually known amounts of pesticides ("flower method"; Ladurner et al., 2003). With this method, indi- vidual bees were confined in an ice cream cup and offered the test solution in a natural flower whose reproductive column had been removed and replaced with a tiny ampoule into which the test solution was pipetted. We compared the effectiveness of the flower method with two other methods commonly used with bees not performing trophallaxis ("film canister" and "glass vial" methods; after Johansen et al., 1984; van der Steen et al., 1996; Bortolotti et al., 2002; Patetta et al., 2002) and tested the three methods on two solitary species, $O$. lignaria and Megachile rotundata (Fabricius) (Megachilidae), and one social species, A. mellifera (Ladurner et al., 2003). The flower method turned out to be a simple, highly effective procedure: under artificial light, the percentage of bees that consumed the test solution within $1 \mathrm{~h}$ (percent feeding success) ranged

\footnotetext{
* Corresponding author: eladurner@entom.agrsci.unibo.it
}

${ }^{1}$ Manuscript editor: Jean Noël Tasei 
from 80 to $95 \%$ in all three bee species. With the other two feeding methods under artificial light, percent feeding success varied from 10 to $60 \%$ in A. mellifera and M. rotundata and was $0 \%$ in $O$. lignaria. Due to its high success rate, the flower method proved efficient for both feeding unit preparation and rearing or capture of bee specimens, and could thus help simplify laboratory oral toxicity tests on a diversity of bee species.

To further decrease feeding unit preparation, in 2003 we investigated the possibility of substituting natural flowers with artificial flowers. Although artificial flowers can conform to an endless array of designs, our objective was not to find an artificial flower preference "profile" for different bee species. Thus, we did not test a range of shape/color/scent permutations. Rather, our objective was to explore whether a standard type of artificial flower would be satisfactory as an individual feeding method in bee toxicology studies, further simplifying the assay.

In honey bees and bumble bees, response to visual and olfactory stimuli may be conditioned by previous experience (Menzel, 1967, 1968; Heinrich et al., 1977). Thus, response to our feeding method might differ between naive (newly-emerged) and experienced bees (with foraging experience).

It is known that $A$. mellifera quickly learn to associate visual and olfactory stimuli with food sources (Menzel, 1968; Koltermann, 1969; Gould and Gould, 1988; von Frisch, 1993). Similar studies are lacking for $O$. lignaria and $M$. rotundata, but learning capacity has been shown in other solitary bee species (Dukas and Real, 1991; Steinmann and Menzel, 1990). Therefore, response to artificial flowers, and thus success of our feeding method, could also be dependent on training. For these reasons, we decided to test naive and experienced $O$. lignaria and $M$. rotundata (only experienced A. mellifera were used), and trained and untrained individuals of all three species.

\section{MATERIALS AND METHODS}

\subsection{Artificial flower design}

To select an appropriate artificial flower design, we relied on previous pollinator studies using artifi- cial flowers (e.g. Waddington, 1980, 1982; Real, 1981; Shafir, 1994; Gegear and Laverty, 1998; review in Kearns and Inouye, 1993), and on the abundant information available for honey bees and bumble bees (Koltermann, 1969; Kriston, 1973; Gould and Gould, 1988; Lunau, 1990; von Frisch, 1993; Menzel and Müller, 1996; Abramson et al., 1997; Wenner, 1998a, b; Gumbert, 2000; Simmonds and Plowright, 2004). We know of no similar studies using artificial flowers for $O$. lignaria or M. rotundata.

When visiting a flower, honey bee and bumble bee foragers are subject to a conditioning process by which floral cues, such as color, odor, and shape, are memorized after being associated with a food reward. Naive honey bees and bumble bees seem to have an innate preference for blue and yellow colors (Lunau, 1990; Giurfa et al., 1995; Gumbert, 2000; Simonds and Plowright, 2004). We therefore made artificial blue flowers with yellow nectar guides (Fig. 1). We used colored tape (VWR Scientific Label tape) with mixed colors to build the flowers.

With regard to flower shape, honey bees have an innate preference for complexity, and spontaneously fly towards symmetrical patterns (Menzel, 1967; Free, 1970; Lehrer et al., 1995; Giurfa et al., 1996). Bumble bees also prefer radial, flower-like patterns over concentric patterns and unpatterned stimuli (Simonds and Plowright, 2004). We therefore arranged a symmetrical array of eight blue petals $(1.3 \times 0.5 \mathrm{~cm})$ around a well drilled into the center of a green florists' dry foam cube $(3 \times 3 \times 1 \mathrm{~cm})$ from FloraCraft Corporation, Ludington, MI. Radial $(0.9 \times 0.1 \mathrm{~cm})$ and central (inside diameter $0.5 \mathrm{~cm}$, outside diameter 0.6 diameter) yellow nectar guides were placed on the petals (Fig. 1). A tiny plastic ampoule (inside diameter $2 \mathrm{~mm}$, outside diameter $3 \mathrm{~mm}$, height $5 \mathrm{~mm}$ ), in which the test solution could be later pipetted, was inserted into the well. The plastic ampoule was built as described in Ladurner et al. (2003).

Honey bee foragers typically learn odors to a level of $90-95 \%$ correct choices after $1-4$ visits (Koltermann, 1969; Gould and Gould, 1988). We scented our artificial flowers with lavender oil. A piece of filter paper (diameter $0.5 \mathrm{~cm}$ ) soaked in $4 \mu \mathrm{L}$ of diluted lavender oil (pure lavender oil from Aura Cacia ${ }^{\circledR}$, Norway, IA, diluted in paraffin oil 1:100 by volume) was placed inside the well of the artificial flower, beneath the plastic ampoule.

\subsection{Bees}

\subsubsection{Experience}

We tested $O$. lignaria and $M$. rotundata females that were either naive (newly emerged bees that had 


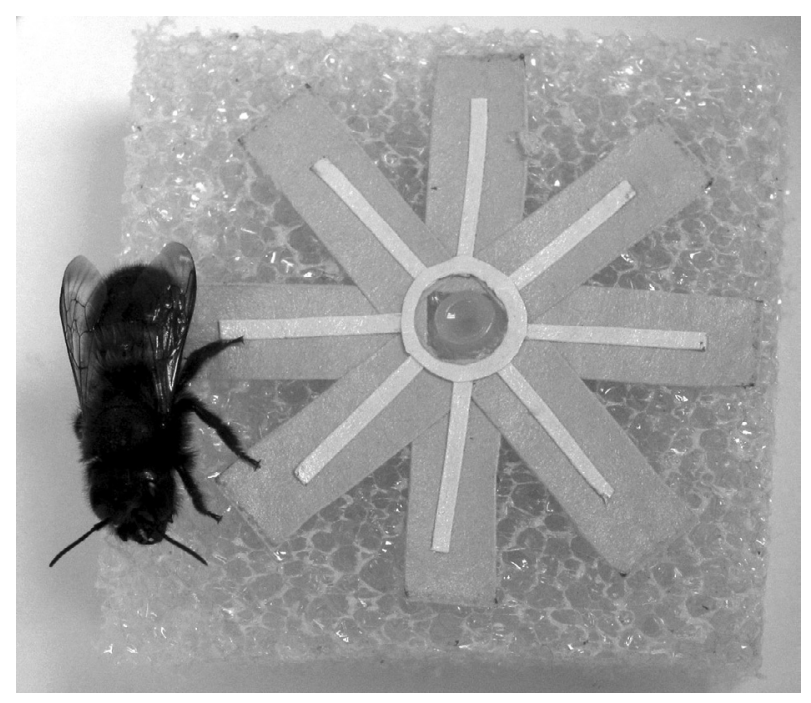

Figure 1. Osmia lignaria female on artificial flower with blue petals and yellow nectar guides on a green platform.

never visited a flower) and experienced (bees that had already foraged on natural flowers). We only tested experienced $A$. mellifera foragers.

To obtain naive $O$. lignaria and $M$. rotundata, wintering females within their cocoons from populations reared at the Bee Biology and Systematics Laboratory, Logan, Utah, were incubated until emergence at $25^{\circ} \mathrm{C}$ and $29^{\circ} \mathrm{C}$, respectively. Upon emergence, females were transferred to a screened flight cage $(40 \times 30 \times 30 \mathrm{~cm})$ at room temperature $\left(22{ }^{\circ} \mathrm{C}\right)$ to allow them to deposit meconium, and were tested the next morning.

Experienced $O$. lignaria and $M$. rotundata females were obtained from active nesting units adjacent to the laboratory. Osmia lignaria nesting units were made of solid wood blocks with paper straws (diameter $7.5 \mathrm{~mm}$ ) inserted in 15-cm holes drilled into the wood blocks (Bosch and Kemp, 2001). For $M$. rotundata we used polystyrene nesting blocks (Beaver Plastics Ltd, Alberta, Canada), with paper straws (diameter $6 \mathrm{~mm}$, length $8.75 \mathrm{~cm}$ ) inserted into the holes. After sunset, we inspected all paper straws with a flashlight. Paper straws containing females were removed with a pair of forceps, plugged with a cotton ball at each end, and brought to the laboratory. In the laboratory, the cotton balls were removed, and the straws were transferred into a flight cage and kept in the dark at room temperature $\left(22^{\circ} \mathrm{C}\right)$ overnight. The next morning, bees exiting the paper straws were captured and assigned to the different treatments. No chilling was necessary for either $O$. lignaria or $M$. rotundata.

Experienced A. mellifera foragers were captured in the morning at the entrance of a queen-right, healthy hive and brought to the laboratory, where they were chilled for a maximum of $30 \mathrm{~min}$ at $4{ }^{\circ} \mathrm{C}$.

\subsubsection{Training}

Bees collected as explained above were considered "untrained". To train individuals, groups of 10 $O$. lignaria, M. rotundata, or Apis mellifera were transferred to holding cages containing an artificial flower feeder. Holding cages consisted of waxed cardboard ice cream cups (diameter $8 \mathrm{~cm}$, height $5 \mathrm{~cm}$ ) from Sweetheart Cup Company Inc., Chicago, IL, covered with a plastic Petri dish lid. A wire mesh screen insert (diameter $7 \mathrm{~cm}$, mesh size $2 \times 1 \mathrm{~mm}$ ) in the Petri dish lid provided adequate aeration. The feeder consisted of an artificial flower like those described above in Section 2.1, but with a central hole (diameter $0.5 \mathrm{~cm}$ ). The artificial flower was fitted with a 5 mL-sample vial (Nalge Nunc International) with a lid. The sample vial contained a sucrose solution ( $25 \%$ volume), with a soaked cigarette filter, inserted through the lid of the vial, and protruding through the central hole of the flower. For those bees assigned to treatments with scented flowers, a piece of filter paper $(1.0 \times 0.3 \mathrm{~cm})$ soaked with $8 \mu \mathrm{L}$ of floral scent (pure lavender oil diluted in paraffin oil, 1:100 by volume) was taped on the lid of the sample vial, underneath the artificial flower.

Holding cages (each with 10 bees and 1 artificial flower feeder), were kept in an incubator for $24 \mathrm{~h}$ (temperatures: $22{ }^{\circ} \mathrm{C}$ for $O$. lignaria, and $25^{\circ} \mathrm{C}$ for $M$. rotundata and $A$. mellifera; relative humidity 60 $80 \%$, photoperiod $12: 12 \mathrm{~h}$ light:dark). The artificial feeder was removed the next morning. Osmia 
Table I. Percent feeding success in Osmia lignaria and Megachile rotundata females, and Apis mellifera foragers offered $10 \mu \mathrm{L}$ of sugar solution using three different flower types $(\mathrm{n}=30 \mathrm{per}$ species/flower type).

\begin{tabular}{lccccc}
\hline \multirow{2}{*}{ Bee species } & Experience & Training & \multicolumn{3}{c}{ Flower type } \\
\cline { 3 - 6 } O. lignaria & & no & Unscented artificial & Scented artificial & Natural \\
& no & yes & 30 & 0 & 90 \\
& no & no & 30 & 57 & $/$ \\
& yes & yes & 30 & 33 & $/$ \\
M. rotundata & no & no & 3 & 50 & 87 \\
& no & yes & 0 & 3 & $/$ \\
& yes & no & 7 & 13 & $/$ \\
A. mellifera & yes & yes & 0 & 20 & / \\
& yes & no & 70 & 77 & 97 \\
\hline
\end{tabular}

lignaria and $M$. rotundata females were then starved for $24 \mathrm{~h}$, and A. mellifera workers for $4 \mathrm{~h}$, prior to being tested.

\subsection{Assays}

Feeding units consisted of holding cages as described in Section 2.2, each containing one flower and one bee. Feeding units were placed in an incubator below two $15 \mathrm{~W}$ Cool White Sylvania ${ }^{\circledR}$ fluorescent tubes (Ladurner et al., 2003). Ten $\mu \mathrm{L}$ of test solution $(25 \% \mathrm{v} / \mathrm{v}$ sucrose in water), pipetted into the plastic ampoule, were offered to each bee for $1 \mathrm{~h}$ Ampoules were then visually inspected and scored as either empty or full (the bee had not consumed the solution). Because scent-marking of flowers has been reported in several bee species (Frankie and Vinson, 1977; Cameron, 1981; Schmitt and Bertsch, 1990; von Frisch, 1993), each flower was used only once.

Temperatures during tests were $22 \pm 2{ }^{\circ} \mathrm{C}$ for $O$. lignaria, and $25 \pm 2{ }^{\circ} \mathrm{C}$ for $M$. rotundata and A. mellifera. Sample sizes were 30 individuals of each species per flower.

For comparative purposes, we also tested 30 untrained individuals of each species (naive $O$. lignaria and $M$. rotundata, experienced A. mellifera) using the natural flower method (Ladurner et al., 2003) with periwinkle (Vinca minor L.) flowers. The reproductive column was substituted with a plastic ampoule, identical to the one described above, and inserted into a well drilled into a piece of green florists' dry foam identical to that used with artificial flowers.

\subsection{Statistical analysis}

We used a Logit model (PROC GENMOD, SAS Institute Inc., 1989; Allison, 1999), to evaluate the effect of scent, experience and training on the proportion of bees that fed from the artificial flowers.

In this study, accommodations were required for two types of zero values in our contingency tables that caused problems with the performance of computational algorithms. First, structural zeros occurred because the experimental design was not balanced, due to the lack of inexperienced A. mellifera as described above. To address structural zeros, we used the standard method of simply deleting them prior to estimating the model with PROC GENMOD (Agresti, 1990; Allison, 1999). Second, zeros occurred in the contingency tables because some of the values were zero, so we added $10^{-6}$ to all contingency table cells and performed sensitivity analyses to confirm minimal impact on parameter estimates and goodness of fit statistics, as recommended by Agresti (1990). Because different bee species were tested under different temperatures and after different starvation periods, we analyzed the data from each species separately.

\section{RESULTS}

Naive, untrained $O$. lignaria did not feed at all, irrespective of the presence of scent (Tab. I). Both experience and training significantly increased feeding success rates (percentage of bees that consumed the test solution within $1 \mathrm{~h}$ ) on the artificial flower (Tab. II). The experience-training interaction was significant (Tab. II) because training increased feeding rates in inexperienced bees more so than in experienced bees (Tab. I). However, the presence of scent did not result in an increased proportion of feeding bees (Tab. II). Even with 
Table II. Results of the Logit model analyzing feeding success on artificial flowers as a function of experience, training and scent.

\begin{tabular}{lccccccc}
\hline Source & DF & \multicolumn{2}{c}{ O. lignaria } & \multicolumn{2}{c}{ M. rotundata } & \multicolumn{2}{c}{ A. mellifera } \\
\cline { 2 - 8 } & & Chi-square & $P$ & Chi-square & $P$ & Chi-square & $P$ \\
\hline experience & 1 & 19.91 & $<0.0001$ & 2.97 & 0.0846 & $/$ & $/$ \\
training & 1 & 33.51 & $<0.0001$ & 0.91 & 0.3403 & 14.14 & 0.0002 \\
scent & 1 & 2.71 & 0.1000 & 2.00 & 0.1573 & 0.05 & 0.8259 \\
experience $\times$ training & 1 & 23.38 & $<0.0001$ & 0.91 & 0.3403 & $/$ & $/$ \\
experience $\times$ scent & 1 & 0.12 & 0.7261 & 2.00 & 0.1572 & $/$ & $/$ \\
training $\times$ scent & 1 & 0.80 & 0.3704 & 6.13 & 0.0133 & 0.05 & 0.8259 \\
\hline
\end{tabular}

trained bees, percent feeding success never reached $60 \%$ (Tab. I).

Percent feeding success in $M$. rotundata was very low, and never exceeded $20 \%$ (Tab. I), irrespective of experience, training or scent (Tab. II). Only the training-scent interaction was marginally significant (Tab. II).

Independent of the presence of scent, training significantly increased feeding success in A. mellifera (Tab. II): $97 \%$ of trained workers consumed the test solution in $1 \mathrm{~h}$ versus 70$77 \%$ of untrained workers (Tab. I).

Feeding success on the natural flower was near $90 \%$ in all three bee species (naive, untrained $O$. lignaria and $M$. rotundata, and experienced, untrained $A$. mellifera).

\section{DISCUSSION}

\subsection{Feeding success}

Overall, feeding success on artificial flowers was much higher for A. mellifera than $O$. lignaria or $M$. rotundata. We posit two possible explanations for this result. First, workers of social species are less likely to be constrained in their foraging behavior than most other insects (Goulson, 2003). In a previous study, $A$. mellifera also performed better than $O$. lignaria and $M$. rotundata on artificial feeding units (Ladurner et al., 2003). Second, to select the standard artificial flower design and the training procedure for our experiments, we relied primarily on information available for honey bees (Koltermann, 1969; Kriston, 1973; Gould and Gould, 1988; von Frisch, 1993;
Menzel and Müller, 1996). Untrained A. mellifera foragers may have learned and memorized various flower color/odor/shape combinations prior to being captured at the hive entrance. Their ability to generalize and their dynamic memory storage and recall processes may have helped them identify the artificial flower as a food source (Smith, 1991; Menzel et al., 1993; Giurfa et al., 1996, 2003; Sandoz et al., 2001). Feeding success in trained A. mellifera was almost $100 \%$, whether or not the artificial flower was scented. In A. mellifera foragers, information about a rewarding floral source is consolidated into a long-term memory within 10-15 minutes, where it remains until death or until re-learning occurs (Menzel, 1968; Menzel and Müller, 1996). Our training lasted $24 \mathrm{~h}$, and thus the honey bees had plenty of time to learn and memorize the odor, color and shape of the artificial flower.

On the natural flower, feeding success was high for all three species (87-90\%), corroborating the results obtained in our previous study with smaller sample sizes (Ladurner et al., 2003). Even naive $O$. lignaria and $M$. rotundata females were spontaneously attracted to the natural flower.

\subsection{Scent}

Even though experienced and trained bees performed better on scented artificial flowers than on unscented flowers in all bee species, scent had no significant effect in any of the three species tested. Among floral stimuli, the odor-food association is known to be the most efficient for the recognition of floral sources in honey bees, but the response of experienced 
honey bees to an odor depends on the odor to which they have been previously conditioned (Kriston, 1973; Smith, 1991; Menzel et al.; 1993; Hosler and Smith, 2000). With trained bees, the duration of the training procedure ( $24 \mathrm{~h}$ ) may have determined that the increase in feeding success on scented artificial flowers failed significance.

The lavender odor could also have reached saturation in the limited volume of the holding cages, and it would then act as an incentive rather than as a cue for the bees. However, to know the exact concentration of an odorant, the number of odorant molecules per unit air volume should be measured, which was beyond the intended scope of our study.

\subsection{Experience}

Experience had a significant effect in $O$. lignaria but not in $M$. rotundata. Only experienced $A$. mellifera were tested. Official guidelines recommend the use of $A$. mellifera foragers for acute toxicity studies, because they are considered to be more likely directly exposed to pesticides (EPA, 1996; OEPP/EPPO, 1992, 2001). No official guidelines exist for solitary bees. However, naive solitary, female bees begin foraging shortly after emergence, and may be immediately exposed to pesticide sprays. In fact, Taséi (1977) and Johansen et al. (1983) recommend using 1- to 2-day-old bees for toxicity studies with $M$. rotundata. The toxicity of pesticides to bees is age-dependent (Ladas, 1970; Guez et al., 2001; Taséi, 2002). Using newly emerged bees in acute toxicity studies would allow testing bees of the same age, and monitoring emergence would allow investigating age-dependent effects of pesticides on both solitary and social bees.

\subsection{Training}

Training significantly increased feeding success rates in $A$. mellifera and $O$. lignaria, but not in $M$. rotundata. However, while none of the untrained $A$. mellifera foragers died when immediately transferred on the flower upon chilling, $10 \%$ of the trained honey bees died in the holding cages during the test, and had to be substituted. The training procedure probably exposed honey bees to excessive stress, resulting in increased mortality. In acute toxicity tests, bees should be stressed as little as possible to prevent biasing of data (Ladas, 1970; Wahl and Ulm, 1983; OEPP/EPPO, 1992, 2001). In O. lignaria, the improvement in feeding success achieved with training (trained vs. untrained bees: $30-57 \%$ vs. 0-33\%), even though significant, was not large enough to justify its use in acute oral toxicity studies: too much extra time would be involved in terms of feeding unit preparation and training procedure, and too many extra bees would be necessary compared with the natural flower method (Ladurner et al., 2003). At least three groups of 10 or more bees should be tested at each concentration of a test solution in toxicity tests (OEPP/EPPO, 1992, 2001). In M. rotundata, feeding success was very low, and never exceeded $20 \%$ irrespective of experience, training or scent.

It could be that we did not choose the appropriate artificial flower design and/or training procedure for every species. However, as already mentioned, our objective was to explore whether one standard type of artificial flower could be used as an individual feeding method in bee toxicology studies.

\subsection{Concluding remarks}

Although our training procedure and artificial flower design were highly effective for A. mellifera, they did not provide an effective method to successfully feed individual bees of all three species. Other flower designs and/or training procedures could be investigated in future studies, but our results suggest that different species may require different flower designs, and that training (with the extra time involved) may be necessary to achieve optimal feeding rates. However, the natural flower method was highly effective with all species tested, confirming the results in Ladurner et al. (2003) and did not require training. For these reasons, we recommend its use in acute oral toxicity tests in the laboratory.

\section{ACKNOWLEDGEMENTS}

We are grateful to G. Trostle and S. Kalaskar for their help throughout the study. We also thank Rosalind James and James H. Cane for their useful comments on a draft of the manuscript. Susan Durham, Dept. of Biology, Utah State University, 
Logan UT provided helpful insight in addressing zeros in contingency table analyses.

This study was partially supported by a Ph.D. scholarship from the University of Bologna to E. L.

Résumé - Évaluation d'un dispositif de fleur artificielle pour administrer individuellement à des abeilles des quantités connues de pesticides. La toxicité orale est souvent ignorée dans les études de toxicité des diverses espèces d'abeilles ne pratiquant pas la trophallaxie, parce qu'il est difficile de les nourrir individuellement. Nous avons étudié la possibilité d'administrer des quantités connues de pesticides individuellement à des abeilles en utilisant un type de fleur artificielle standardisée. La fleur artificielle a une structure radiale comportant huit pétales bleus et des « enseignes à nectar » jaunes avec au centre une ampoule pour le nourrissement (Fig. 1). Nous avons comparé des fleurs parfumées (avec de l'essence de lavande diluée dans de l'huile de paraffine) et non parfumées. Nous avons testé des femelles d'osmies (Osmia lignaria) et de mégachiles (Megachile rotundata) expérimentées et naïves et des ouvrières d'abeilles domestiques (Apis mellifera) expérimentées, de même que des individus des trois espèces conditionnés ou non. Les abeilles naïves étaient des abeilles naissantes et les abeilles expérimentées ont été capturées au nid. Pour conditionner les abeilles, nous les avons laissées $24 \mathrm{~h}$ dans une cagette avec un nourrisseur fixé à une fleur artificielle identique à la fleur test. Nous avons aussi testé des individus non conditionnés des trois espèces sur des unités de nourrissement constituées de fleurs naturelles (Ladurner et al., 2003). Pour cela une ampoule avec la solution à tester a été fixée à une fleur de pervenche (Vinca minor) après élimination de la colonne sexuelle. Dans tous les cas, les fleurs avec la solution à tester $(10 \mu \mathrm{L}$ d'une solution aqueuse de saccharose à $25 \%$ v/v) ont été proposées à des abeilles encagées individuellement durant $1 \mathrm{~h}$. Les tests ont été faits sous lumière artificielle à $22^{\circ} \mathrm{C}$ pour $O$. lignaria et à $25{ }^{\circ} \mathrm{C}$ pour $M$. rotundata et A. mellifera. Au total, le succès du nourrissement ou S.N. (pourcentage d'abeilles ayant consommé la solution à tester en $1 \mathrm{~h}$ ) sur les fleurs artificielles a été beaucoup plus faible (0-50\%) pour $O$. lignaria et $M$. rotundata que pour $A$. mellifera (70-97\%) (Tab. I). L'odeur n'a eu aucun effet sur le S.N. pour aucune des trois espèces (Tab. II). Le fait d'être expérimenté a significativement amélioré le S.N. pour $O$. lignaria, mais n'a pas donné de résultat significatif pour $M$. rotundata (Tab. II). Le conditionnement a amélioré le S.N. pour O. lignaria (particulièrement pour les individus naïfs) et $A$. mellifera, mais pas pour M. rotundata (Tab. II). Le S.N. avec la méthode de la fleur naturelle a été élevé pour les trois espèces (87-90 \%) (Tab. I). D'autres dispositifs de fleur artificielle pourraient être testés à l'avenir. Nos résultats indiquent néanmoins que différents dispositifs et/ou méthodes de conditionnement pourraient être nécessaires pour nourrir efficacement diverses espèces d'abeilles. Entre-temps nous recommandons la méthode de la fleur naturelle car (1) elle ne nécessite aucun conditionnement, (2) elle est économe en temps et en spécimens d'abeilles et (3) elle est vraisemblablement applicable à une large gamme d'espèces.

Osmia lignaria / Megachile rotundata / Apis mellifera / toxicité orale / test / fleur artificielle

Zusammenfassung - Bewertung einer standardisierten künstlichen Blüte zur Fütterung einzelner Bienen mit festgelegten Pestizidmengen. Die orale Toxizität wird in Toxizitätstests bei Bienenarten ohne kommunalen Futteraustausch wegen der Schwierigkeit der individuellen Fütterung häufig nicht beachtet. Wir untersuchten die Möglichkeit, Einzelbienen mit bekannten Pestizidmengen auf einem Standardtyp einer künstlichen Blüte zu füttern. Die Kunstblüte hatte eine radiale Struktur mit 8 blauen Blütenblättern und gelben Nektarmalen. In der Mitte befand sich eine Futterampulle (Abb. 1). Wir verglichen Blüten mit Duft (Lavendelöl verdünnt in Paraffinöl) mit duftlosen Blüten. Es wurden erfahrene und unerfahrene Osmia lignaria und Megachile rotundata Weibchen und erfahrene Apis mellifera Arbeiterinnen getestet. Außerdem testeten wir sowohl dressierte als auch undressierte Tiere von allen 3 Arten. Unerfahrene Bienen waren frisch geschlüpft, erfahrene wurden an ihren Nestern gefangen. Zur Dressur hielten wir Bienen $24 \mathrm{~h}$ lang in einem Käfig, ausgestattet mit einer dem Test entsprechenden Kunstblüte mit Futtergefäß. Zum Vergleich testeten wir auch untrainierte Bienen aller 3 Arten auf Futtervorrichtungen mit natürlichen Blüten (Ladurner et al., 2003). Diese bestanden aus einer Vinca minor Blüte, in der eine Ampulle mit der Testlösung nach Entfernung des Fruchtknotens befestigt wurde. In allen Versuchen wurden Einzelbienen, denen $10 \mu \mathrm{L}$ Testlösung (25\% Volumeneinheit Sucrose und $75 \%$ Volumeneinheit Wasser) geboten wurde, für eine Stunde im Käfig gehalten. Die Versuche wurden bei künstlichem Licht bei $22{ }^{\circ} \mathrm{C}(O$. lignaria $)$ oder $25{ }^{\circ} \mathrm{C}$ (M. rotundata, A. mellifera) durchgeführt.

Insgesamt war der Erfolg der Fütterung (\% Bienen, die die Testlösung in $1 \mathrm{~h}$ aufnahmen) auf Kunstblüten bei $O$. lignaria und $M$. rotundata viel geringer $(0-50 \%)$ als bei A. mellifera (70-97\%) (Tab. I). Duft hatte bei keiner Art einen Einfluss auf die Futteraufname (Tab. II). Erfahrung verbesserte die Futteraufnahme signifikant bei $O$. lignaria, aber nicht bei $M$. rotundata (Tab. II). Eine Dressur erhöhte die Futteraufnahme nur bei $O$. lignaria (besonders bei naiven Einzeltieren) und A. mellifera (Tab. II). Der Erfolg bei einer Fütterung mit der Methode ,natürliche Blüten“" war bei allen 3 Arten hoch (87-90 \%) (Tab. I).

Kunstblüten in anderen Mustern könnten zukünftig getestet werden. Unsere Ergebnisse weisen jedoch darauf hin, dass unterschiedliche Muster und/oder Dressurmethoden bei verschiedenen Bienenarten 
für eine effektive Fütterung nötig sein könnten. Bis dahin empfehlen wir die Methode ,natürliche Blüten“" zur Fütterung von Einzelbienen: (1) eine Dressur der Bienen entfällt und sie war bei allen 3 getesteten Arten sehr effektiv, (2) sie spart Zeit und Bienen und (3) sie ist wahrscheinlich auf einen weiten Bereich der Arten anwendbar.

Oraler Toxizitätstest / Kunstblüte / Osmia lignaria / Apis mellifera / Megachile rotundata

\section{REFERENCES}

Abramson C.I., Aquino I.S., Silva M.C., Price J.M. (1997) Learning in the africanized honey bee: Apis mellifera L., Physiol. Behav. 62, 657-674.

Agresti A. (1990) Categorical data analysis, John Wiley \& Sons, New York.

Allison P.D. (1999) Logistic regression using the SAS System: Theory and application, SAS Institute Inc., Cary, NC.

Bortolotti L., Porrini C., Sbrenna G. (2002) Effetti dell'imidacloprid nei confronti di Bombus terrestris (L.), Prove di laboratorio, Inf. Fitopatol. 3, 6671 .

Bosch J., Kemp W.P. (2001) How to manage the blue orchard bee as an orchard pollinator, Handbook Series, Book 5, Sustainable Agriculture Network, Beltsville, MD.

Bosch J., Kemp W.P. (2002) Developing and establishing bee species as crop pollinators: the example of Osmia spp. (Hymenoptera: Megachilidae) and fruit trees, Bull. Entomol. Res. 92, 3-16.

Cameron S.A. (1981) Chemical signals in bumblebee foraging, Behav. Ecol. Sociobiol. 9, 257-260.

Dukas R., Real L.A. (1991) Learning foraging tasks by bees: a comparison between social and solitary species, Anim. Behav. 42, 269-276.

EPA (1996) Ecological effects test guidelines OPPTS 850.3020 , Honey bee acute contact toxicity US EPA.

Frankie G.W., Vinson S.B. (1977) Scent marking of passion flowers in Texas by females of Xylocopa virginica texana (Hymenoptera: Anthophoridae), J. Kans. Entomol. Soc. 50, 613-625.

Free J.B., (1970) Effect of flower shapes and nectar guides on the behaviour of foraging honeybees, Behaviour 37, 269-285.

Gegear R.J., Laverty T.M. (1998) How many flower types can bumble bees work at the same time? Can. J. Zool. 76, 1358-1365.

Giurfa M., Núñez J., Chittka L., Menzel R. (1995) Colour preferences of flower-naive honeybees, J. Comp. Physiol. A 178, 699-709.
Giurfa M., Eichmann B., Menzel R. (1996) Symmetry perception in an insect, Nature 382, 459-461.

Giurfa M., Schubert M., Reisenman C., Gerber B., Lachnit H. (2003) The effect of cumulative experience on the use of elemental and configural vision discrimination strategies in honeybees, Behav. Brain Res. 145, 161-169.

Gould J.L., Gould C.G. (1988) The honey bee, Scientific American Library, New York.

Goulson D. (2003) Bumblebees, behaviour and ecology, Oxford University Press, Oxford, UK.

Guez D., Suchail S., Gauthier M., Maleszka R., Belzunces L. (2001) Contrasting effects of imidacloprid on habituation in 7- and 8-day-old honeybees (Apis mellifera), Neurobiol. Learn. Mem. 76, 183-191.

Gumbert A. (2000) Color choices by bumble bees (Bombus terrestris): innate preferences and generalization after learning, Behav. Ecol. Sociobiol. $48,36-43$.

Heinrich B., Mudge P.R., Deringes P.G. (1977) Laboratory analysis of flower constancy in foraging bumblebees: Bombus ternarius and B. terricola, Behav. Ecol. Sociobiol. 2, 247-265.

Hosler J.S., Smith B.H. (2000) Blocking and the detection of odor components in blends, J. Exp. Biol. 203, 2797-2806.

Johansen C.A., Mayer D.F., Eves J.D., Kious C.W (1983) Pesticides and bees, Environ. Entomol. 12, 1513-1518.

Johansen C.A., Rincker C.M., George D.A., Mayer D.F., Kious C.W. (1984) Effects of Aldicarb and its biologically active metabolites on bees, Environ. Entomol. 13, 1386-1398.

Kearns C.A., Inouye D.W. (1993) Techniques for pollination biologists, University Press of Colorado, Niwot, Colorado.

Koltermann R. (1969) Lern- und Vergessensprozesse bei der Honigbiene - aufgezeigt anhand von Duftdressuren, Z. Vgl. Physiol. 63, 310-334.

Kriston I. (1973) Die Bewertung von Duft- und Farbsignalen als Orientierungshilfen an der Futterquelle durch Apis mellifera L., J. Comp. Physiol. 84, 77-94.

Ladas A. (1970) Der Einfluss verschiedener Konstitutions- und Umweltfaktoren auf die Anfälligkeit der Honigbiene (Apis mellifica L.) gegenüber zwei insektiziden Pflanzenschutzmitteln, Diplomarbeit, Hohe Landwirtschaftliche Fakultät, Rheinische Friedrich-Wilhelm-Universität, Bonn, Germany.

Ladurner E., Bosch J., Maini S., Kemp W.P. (2003) A method to feed individual bees (Hymenoptera: Apiformes) known amounts of pesticides, Apidologie 34, 597-602.

Lehrer M., Horridge G.A., Zhang S.W., Gadagkar R. (1995) Shape vision in bees: innate preferences for 
flower-like patterns, Philos. Trans. R. Soc. London, Part B 347, 123-137.

Lunau K. (1990) Colour saturation triggers innate reactions to flower signals: flower dummy experiments with bumblebees, J. Comp. Physiol. A 166, 827-834.

Menzel R. (1967) Untersuchungen zum Erlernen von Spektralfarben durch die Honigbiene, Z. Vgl. Physiol. 56, 22-62.

Menzel R. (1968) Das Gedächtnis der Honigbiene für Spektralfarben, Z. Vgl. Physiol. 60, 82-102.

Menzel R., Müller U. (1996) Learning and memory in honeybees: from behavior to neural substrates, Annu. Rev. Neurosci. 19, 249-266.

Menzel R., Greggers U., Hammer M. (1993) Functional organization of appetitive learning and memory in a generalist pollinator, the honey bee, in: Papaj D.R., Lewis A.C. (Eds.), Insect learning, Chapman Hall, New-York, pp. 79-125.

OEPP/EPPO (1992) Guideline on test methods for evaluating the side-effects of plant protection products on honeybees, Directive PP 1/170, Bull. OEPP/EPPO 22, 203-215.

OEPP/EPPO (2001) Revised draft of EPPO Guidelines PP 1/170: Guidelines for the efficacy evaluation of plant protection products: side-effects on honeybees. Appendix I, in: INRA (Ed.), Hazards of pesticides to bees, Les Colloques de l'INRA, $\mathrm{n}^{\circ}$ 98, Paris, pp. 279-288 also publ. in Bull. OEPP/ EPPO 31, 323-330

Patetta A., Marletto F., Manino A. (2002) Pesticides and bumblebees: poisoning tests in the laboratory, Insect Soc. Life 4, 101-106.

Real L.A. (1981) Uncertainty and pollinator-plant interactions: the foraging behavior of bees and wasps on artificial flowers, Ecology 62, 20-26.

Sandoz J.C., Pham-Delegue M.H., Renou M., Wadhams L.J. (2001) Asymmetrical generalisation between pheromonal and floral odours in appetitive olfactory conditioning of the honey bee (Apis mellifera L.), J. Comp. Physiol. A 187, 559-568.

SAS Institute Inc. (1989) SAS/STAT User's guide, Version 6. Cary, NC.

Schmitt D.W., Bertsch A. (1990) Do foraging bumblebees scent-mark food sources and does it matter? Oecologia 82, 137-144.

Shafir S. (1994) Intransitivity of preferences in honey bees - support for comparative evaluation of foraging options, Anim. Behav. 48, 55-67.
Simonds V., Plowright C.M.S. (2004) How do bumblebees first find flowers? Unlearned approach responses and habituation, Anim. Behav. 67, 379386.

Smith B.H. (1991) The olfactory memory of the honeybee Apis mellifera. 1. Odorant modulation of short- and intermediate-term memory after singletrial conditioning, J. Exp. Biol. 161, 367-382.

Steinmann E., Menzel R. (1990) Lernversuche mit der Einsiedlerbiene Osmia rufa (Linnaeus, 1758) (Hymenoptera, Apoidea), Mitt. Schweiz. Entomol. Ges. 63, 99-103.

Taséi J.-N. (1977) Méthode de test de toxicité des insecticides applicable aux abeilles solitaires et plus particulièrement a Megachile pacifica Panz. (Hymenoptera, Megachilidae), Apidologie 8, 129-139.

Taséi J.-N. (2002) Impact of agrochemicals on nonApis bees, in: Devillers J., Pham-Delègue M.-H. (Eds.), Honey bees: estimating the environmental impact of chemicals, Taylor \& Francis, London, pp. 101-131.

Van der Steen J.J.M., Gretenkord C., Schaeffer H. (1996) Methods to determine acute oral and contact LD50 of pesticides for bumblebees (Bombus terrestris L.), Appendix 28, in: Lewis G. (Ed.), Proceedings of the VIth Int. Symp. on Hazards of pesticides to bees, Braunschweig.

von Frisch K. (1993) The dance language and orientation of bees, Harvard University Press, Cambridge Massachusetts, London, England.

Waddington K.D. (1980) Flight patterns of foraging bees relative to density of artificial flowers and distribution of nectar, Oecologia 44, 199-204.

Waddington K.D. (1982) Honey bee foraging profitability and round dance correlates, J. Comp. Physiol. 148, 297-301.

Wahl O., Ulm K. (1983) Influence of pollen feeding and physiological condition on pesticide sensitivity of the honey bee Apis mellifera carnica, Oecologia 59, 106-128.

Wenner A.M. (1998a) Odors, wind and colony foraging - Part I of three parts: the need for odor, Am. Bee J. 138, 746-748.

Wenner A.M. (1998b) Odors, wind and colony foraging - Part II of three parts: the role of wind direction, Am. Bee J. 138, 807-810. 